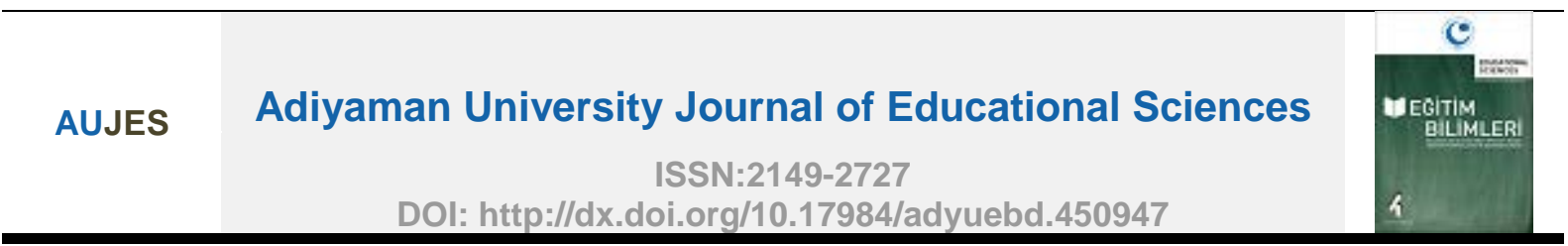

\title{
The Current Situation of Social Studies Teaching Trainings in Turkey University (2017)*
}

\author{
Halil TOKCAN ${ }^{1 * *}$, Arife TiLKi \\ ${ }^{1}$ Niğde Ömer Halisdemir University Department of Social Studies Education, Niğde \\ 2. Niğde Ömer Halisdemir University Graduate School of Education Sciences, Graduate Student, Niğde
}

\begin{tabular}{l} 
ARTICLE INFO \\
\hline Article History: \\
Received \\
04.08.2018 \\
Received in revised \\
form 20.12.2018 \\
Accepted \\
31.12.2018 \\
Available online \\
31.12.2018
\end{tabular}

\begin{abstract}
The main purpose of this research is to present the current status of the Department of Social Studies Education in Turkey in 2017. In this study, the number of students studying in Social Studies Education Department in 2017 , the number of faculty members working in this department, the number of students enrolled in this department change according to the years and universities and the number of appointments of social studies teaching between 2013-2017. In this study, qualitative research methods were used. While determining the number of students in the department and the base points of the program, the information in the OSYM guide for the last 4 years was taken into consideration in determining the number of faculty members and the internet pages of the related departments were taken into consideration in determining the number of faculty members. According to the results of the research, the Department of Social Studies Education actively carries out education activities in 59 universities in Turkey as of 2017. Based on the quota of LYS, the total number of students in the Department of social studies teaching is 15.639. It is observed that the scores of the Department of social studies teaching are quite variable. The highest score student placed in social studies teacher program in 2016 is 25,800 while the lowest score student's score is 75,900 . According to the data of the year 2013-2017, Istanbul University is the University preferred by the highest scores students who are placed in social studies teaching program. As a result of the research, it was determined that the number of students who were placed in the Department of social studies teaching of universities is very high compared to the number of appointments and therefore there are approximately 27,500 people waiting to be appointed. Due to the increase in the number of students waiting for the appointment, the number of candidates taking the ÖABT social studies exam has been gradually decreasing since 2015. According to the results of the study, the number of quotas of Social Studies Education departments in Turkey is reduced; increasing the number of faculty members can be said to be beneficial in terms of quality and achievement of future goals.

(c) 2018 AUJES. All rights reserved

Keywords:Social Studies, Higher Education, Department of Social Studies Teaching, Degree Program
\end{abstract}

\section{Extended Abstract}

\footnotetext{
*In this study, the 6th International Social Science Education Symposium (USBES 6) in the presented as oral presentations "Current State of Social Studies Education Department in Turkey University (2017)" extended from the study and edited version. **Corresponding author's address: Nigde Omer Halisdemir University, Faculty of Education, Nigde, Turkey e-mail: haliltokcan@gmail.com
} 


\section{Purpose}

The studies initiated in 1996 for the restructuring of the faculties of education started to be implemented since the 1998-1999 academic year. With the new regulation, in the majority of the Faculties of Education, the quota of secondary education branch teachers was reduced. On the other hand, Social Studies, primary education, Turkish, Science and Mathematics Important contingency increases were realized in their teacher programs. Özav, 2001: 165).

The 1997 decision of the Council of Higher Education and the social sciences departments established in the faculties of education started to recruit students in the academic year 1997-1998. Before 1997-1998, the Social Studies Teacher Education undergraduate program was only available in two faculties. The first faculty that opened the Social Studies undergraduate program was Kastomunu Faculty of Education, which was affiliated to Gazi University at the time. It was followed by Celal Bayar University Demirci Faculty of Education, which started the recruitment of students in 1994-1995 academic year. Since 1997-1998, the number of faculty members receiving social studies undergraduate program has reached to 28; The number of places, which were 190, reached 2950, that is, increased by 15 times (Özav, 2001: 166; Kaymakcı, 2012; İbret and Kaymakcı, 2016). In 19981999, all secondary education was closed in 2012 due to the increasing number of graduates of Social Studies teaching programs, which were open to both formal education and secondary education programs.

In this research, university teaching social studies in Turkey the status of an existing department (2017) is intended to be drawn to help put forward a perspective for the future. At the end of the research, the following questions were sought:

1 social studies, students begin the year in which the purchase of teaching departments which are in Turkey.

2. Social studies teaching departments and student numbers with active students

3. Upper and lower rankings of the students who are placed in the social studies teaching department (2013-2017)

4. As of 2017, what is the number of lecturers in the department of Social Studies Education? 5. How are the social studies teaching assignments (2013-2017)?

6. What are the branches of the 2016 KPSS ÖABT exam, their test average, the number of candidates taking the exam and the number of assignments for $2017 ?$

\section{Method}

The research data were collected through qualitative research methods through a document analysis. A document analysis involves analyzing of written materials that contain information about the cases or phenomena targeted for investigation. A document review 
enables the analysis of a research problem based on a wide range of time periods, with documents produced within a certain period of time, or documents produced by multiple sources in different times and at different intervals (Yıldırım ve Şimşek, 2000, pp. 140-143).

\section{Results}

59 university social studies teacher in Turkey according to Table 1 when there are divisions. Before 1997-1998, the Social Studies Teacher Education undergraduate program was only available in two faculties. The first faculty that opened the Social Studies undergraduate program was Kastomunu Faculty of Education, which was affiliated to Gazi University at the time. It was followed by Celal Bayar University Demirci Faculty of Education, which started the recruitment of students in 1994-1995 academic year. Since 1997-1998, the number of faculty members receiving social studies undergraduate program has reached to 28; The number of places, which were 190, reached 2950, that is, increased by 15 times.

When the number of students who are active in social studies teaching is examined in Table 2, the number of students is 15.639. The universities with the highest number of students in 59 universities are Atatürk, Celal Bayar, Cumhuriyet, Dokuz Eylül, Erzincan, Gazi, Karadeniz Teknik (In 2018 the name Trabzon), Kastamonu, Necmettin Erbakan, Niğde Ömer Halisdemir, Pamukkale and Siirt Universities.

Table 3 shows the upper and lower order of LYS scores of students who have been placed in social studies teaching departments according to years (2013-2016). Accordingly, it is seen that the points of social studies teaching program are quite variable. In 2016 , the highest score for the social studies teacher program was 25,800 , while the lowest score for the students was 75,900

When the LYS order of the students with the lowest scores enrolled in the social studies education departments from Table 4 is examined, the big difference between the LYS scores of the teacher candidates placed in the department of social studies education is noteworthy. According to 2013-2016 data, the university preferred by the students with the highest scores in the social studies education departments was İstanbul University. Bartın University was the preferred university with the lowest score.

In Table 5 and Table 6, the number of faculty members increased from 253 in 2008 to 494 in 2017. In other words, approximately two times the number of faculty members has been increased.

When we look at Table 7, we see that the number of appointments of social studies teachers decreased even more over the years. Between the years 2013-2017, the total number of assignments is 5.789 . 
When we look at the number of candidates who took the ÖABT exam in 2013-2017 from Table 8 to 2013-2017, it is seen that the number of candidates increasing between 2013 and 2015 has started to decrease since 2016 and decreased to almost 2013 level (19.179) in 2017 (19.677). The main reason for this situation is the inability of the candidates to take the exam.

Among the candidates who took the ÖABT exam, it was noted that the branches with the lowest candidate / assignment ratio were secondary education ie high school branches, while the branch with the minimum candidate / assignment ratio between the secondary and primary education branches was the teacher of social studies.

\section{Discussion}

Social studies teacher at 59 universities in Turkey today is available in the department. There are 15.639 students in the social sciences education departments with active students. The number of departments of social studies teaching is increasing by years. This situation also increases the number of graduates of the department. The graduates of the department come to this program to become Social Studies teachers. The fact that the employment of the Social Studies teacher in the state staff is limited is causing problems for the program students in the future and in the future and causes loss of motivation. According to the 2016 data, one of the branches with the lowest candidate / assignment ratio according to the number of candidates entering the exam was the social studies teaching program with a ratio of $1.4 \%$.

In 2016, by taking the ÖABT exam in 2017, the lowest rate among primary and secondary school teachers in the teacher candidates who were appointed in 2017 was unfortunately a branch of social studies education. This situation creates a loss of motivation for the candidates graduated from the department of social studies education. The most concrete example of this situation is 2013-2017 social studies. From 2013 to 2015, the number of candidates has increased steadily since 2015 . In 2013 , the number of candidates who took the ÖABT social studies exam was 19.179; 22,267 in 2014; In 2015, 24,611; In 2016 it was 23.749 and in 2017 it was 19.677 people. In 2017, according to the 2016 year examination, the number of candidates who took the ÖABT exam decreased by 4072 or $20.7 \%$. Considering approximately 3800 new graduates in 2016, the number of pre-service teachers in social studies teaching department seems to have lost the prospect of being a teacher.

\section{Conclusion}

The productivity of education and training activities in the departments of Social Studies Teacher is falling due to the large number of students. For this, it is necessary to stop opening new sections and reduce the quota numbers. 
- The number of appointments of the Social Studies Teacher should be increased, the employment opportunities should be increased, thousands of graduate student candidates should be placed in the open positions and appropriate policies should be developed.

-Turkey should develop new policies to train qualified teachers, who are responsible for teacher education, teacher training, should not forget that the most important element of employment.

-The Ministry of Education should put an end to contracted and paid teaching practices and apply ideas that are more beneficial in the distribution of the staff between the teaching branches. 


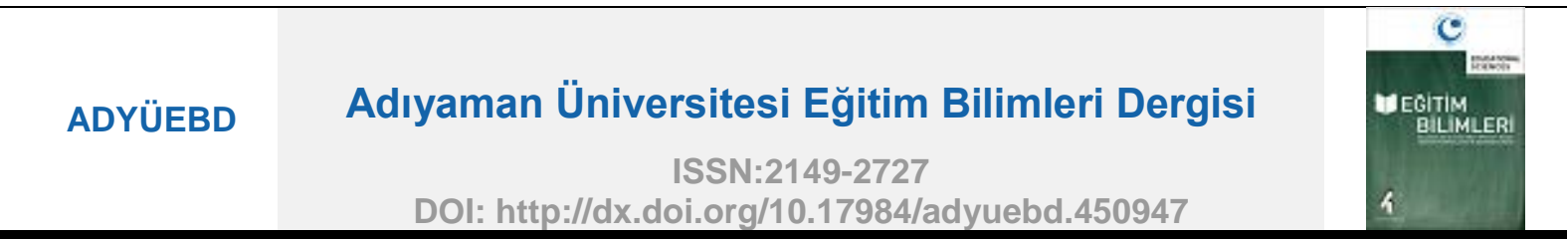 \\ Türkiye'deki Sosyal Bilgileri Eğitimi Lisans Programlarının Mevcut Durumunun İncelenmesi (2017)
}

\author{
Halil TOKCAN ${ }^{1 * *}$, Arife TiLKi ${ }^{2}$
}

${ }^{1}$ Niğde Ömer Halisdemir Üniversitesi, Sosyal Bilgiler Eğitimi Anabilim Dalı, Niğde

${ }^{2}$ Niğde Ömer Halisdemir Üniversitesi, Eğitim Bilimleri Enstitüsü Yüksek Lisans Öğrencisi

MAKALE BILLGI

Makale Tarihçesi:

Alındı 04.08.2018

Düzeltilmiş hali

alındı 20.12.2018

Kabul edildi

31.12.2018

Çevrimiçi

yayınlandı

31.12.2018

\section{ÖZET}

Bu araştırmanın temel amacı Türkiye'deki Sosyal Bilgiler Eğitimi Anabilim Dallarının 2017 yılındaki mevcut durumunu ortaya koymaktır. Araştırmada Sosyal Bilgiler Eğitimi Anabilim Dallarında 2017 yılında öğrenim gören öğrenci sayısı, bu anabilim dalında görev yapan öğretim üyesi sayısı, anabilim dalına kaydolan öğrencilerin puanlarının yıllara göre ve üniversitelere göre değişimi ve sosyal bilgiler öğretmenliğinin 2013-2017 yılları arası atama sayıları incelenmiştir. Araştırmada nitel araştırma yöntemlerinden doküman inceleme yöntemi kullanılmıştır. Araştırma verilerini toplamada anabilim dalındaki öğrenci sayılarını ve programın taban puanlarının belirlenmesinde son 4 yılın ÖSYM kılavuzunda yer alan bilgiler kullanılırken; öğretim üyeleri sayısı belirlemede ise ilgili anabilim dallarının internet sayfaları esas alınmıştır. Araştırma sonuçlarına göre 2017 yılı itibariyle Türkiye'de toplam 59 üniversitede Sosyal Bilgiler Eğitimi Anabilim Dalı aktif olarak eğitim-öğretim faaliyeti göstermektedir. LYS kontenjanları esas alındığında sosyal bilgiler öğretmenliği anabilim dallarında toplam öğrenci 15.639'dur. Sosyal Bilgiler Öğretmenliği anabilim dalının puan sıralarının oldukça değişken olduğu görülmektedir. 2016 yılında Sosyal Bilgiler Öğretmenliği programına yerleşen en yüksek puanlı öğrencinin puan sırası 25.800 iken en düşük puanlı öğrencinin sırası 75.900'dür. 2013-2017 yılın verilerine göre sosyal bilgiler öğretmenliği programına yerleşen en yüksek puanlı öğrencilerin tercih ettikleri üniversite İstanbul Üniversitesi'dir. Araştırma sonucunda üniversitelerin sosyal bilgiler öğretmenliği anabilim dalına yerleşen öğrenci sayısının, atama sayılarına göre çok fazla olduğu bu nedenle atanmayı bekleyen yaklaşık 27.500 kişi olduğu belirlenmiştir. Atama bekleyen öğrenci sayısının artması nedeniyle 2015 yılından itibaren ÖABT sosyal bilgiler sınavına giren aday sayısı git gide azalmaktadır. Çalışma sonuçlarına göre Türkiye'de Sosyal Bilgiler Eğitimi anabilim dallarının kontenjan sayılarının azaltılırken; öğretim üyesi sayısının ise arttırılması kalitenin ve gelecek hedeflerinin tutturulması açısından faydalı olacağı söylenebilir.

(c) 2018 AUJES. Tüm hakları saklıdır Anahtar Kelimeler: Sosyal Bilgiler, Yükseköğretim, Sosyal Bilgiler Öğretmenliği, Lisans Programı

\section{Giriş}

"Sosyal bilgiler nedir?" 20. yüzyıl boyunca bu soruya pek çok kişi çok farklı cevaplar vermiştir. Öztürk'e (2012:4) göre "Sosyal bilgiler, hemen her bakımdan

\footnotetext{
*Bu çalışma 6. Uluslararası Sosyal Bilgiler Eğitimi Sempozyumu (USBES 6)'nda sözlü bildiri olarak sunulan "Türkiye Üniversitelerinde Sosyal Bilgiler Öğretmenliği Anabilim Dallarının Mevcut Durumu (2017)" adlı çalışmanın genişletilmiş ve düzenlenmiş halidir.

**Sorumlu yazarın adresi: Niğde Ömer Halisdemir Üniversitesi, Eğitim Fakültesi, Niğde, Türkiye e-posta: haliltokcan@gmail.com
} 
değişen ülke ve dünya koşullarında bilgiye dayalı karar alıp problem çözebilen etkin vatandaşlar yetiştirmek amacıyla sosyal ve beşeri bilimlerden aldığı bilgi ve yöntemleri kaynaştırarak kullanan bir öğretim programıdır." Sosyal bilgiler alan uzmanları, sosyal bilgileri açıklarken temel amacı vatandaşlık eğitimi olarak kabul etmişlerdir. Ancak Sosyal bilgileri yorumlama ve uygulamada bakış açıları farklı olarak en fazla kabul edilen üç gelenek ortaya çıkmıştır. Sosyal bilgiler öğretimine ilişkin farklı yaklaşımlar, ilk kez 1970 yılında Barth ve Shermis tarafından NCCS'nin yayın organı Social Education'da yayınlanan bir makalede sınıflandırılmıştır. Belli başlı üç kategoride toplanan bu yaklaşımlardan ilki "vatandaşlık aktarımı olarak sosyal bilgiler"dir. Vatandaşlık aktarımında genel amaç, toplumun temel kurum, değer ve inançlarının öğretilerinin telkin ederek, mevcut durumun devamını sağlamaktır. İkinci yaklaşım "sosyal bilim olarak sosyal bilgiler öğretimi"dir. Bu yaklaşımda sosyal bilimlere ait, beceri ve değerlerin kazanılmasının etkili vatandaşlık için en iyi hazırlık olduğu varsayımına dayanır. Öğrenciler sosyal bilimlerin yapısı (onların temel kavramları, genellemeleri ve kuramları) ile ilgili bilgi toplama ve yorumlama süreçlerini öğrenmelidir. "Yansıtıcı düşünce olarak sosyal bilgiler" ise John Dewey'in düşüncelerine dayanmaktadır. Birincil amacı, öğrencilerin problem çözme ve karar alma becerilerini öğrenip uygulamalarını sağlamaktır. Buna paralel olarak, öğrencilerin bireysel ve kamusal problemleri tanımlayıp analiz edebilecekleri ve bunlara yönelik bilgiye dayalı kararlar alabilecekleri öğrenme-öğretme süreçlerine ağırlık vermektedir (Akdağ, 2009:7; Safran, 2011:7-8; Öztürk, 2012:5-6; Kılıçoğlu, 2015:6-7).

Sosyal bilgilerin kapsamına giren derslerin Antik Yunan'a kadar inen geçmişlerine rağmen, yaygın bir şekilde okul programlarına girişi, 20. yy. başlarında ABD' de gerçekleşmiştir. Sosyal bilgiler anlayışı ilerici bir eğitim reformunun önemli bir parçası olarak eğitim-öğretim programlarına yansımıştır. Cumhuriyet Dönemi'nde 1926-1930, 1936 ve 1948 programlarında ayrı olarak tarih, coğrafya ve yurttaşlık bilgisi derslerine yer verilmiştir. Cumhuriyet döneminde Tarih, Coğrafya ve Yurttaşlık Bilgisi dersleri, ilk kez 1962 yılında yayınlanan İlkokul Program Taslağı'nda, disiplinler arası bir yaklaşımla "Toplum ve Ülke İncelemeleri” adı altında birleştirilmiş ve bu ders 1968 yılında "Sosyal Bilgiler" adını almıştır (Sağlamer, 1980; Öztürk-Otluoğlu, 2002; Çetin, 2003:175; Ata, 2007; Kaymakcı, 2012).

Ülkemizde sosyal bilgiler öğretmeni yetiştirmenin tarihçesi bu dersin Türk eğitim sisteminde yer almasıyla doğru orantılıdır. Başka bir ifadeyle 1968 öncesinde sosyal bilgiler öğretmen yetiştirme programlarından söz etmek mümkün değildir. Zira bu döneme egemen olan tek disiplinli yaklaşım anlayışı sosyal bilgiler konularını tarih ve coğrafya öğretmenlerinin okutmasını zorunlu kılmıştır. Bu bağlamda cumhuriyet döneminde Gazi Orta Muallim Mektebi ve Terbiye Enstitüsü bünyesinde tarih-coğrafya bölümünde öğretmen yetiştirilmesiyle başlayan süreç, 1967-1968 öğretim yılından itibaren üç yıllık eğitim enstitülerine bağlı edebiyat bölümünün sosyal bilgiler kısmında devam etmiştir (Altunya, 2006; Bayram, 2003; Öztürk, 2005). Eğitim enstitülerinin 1978-1979 eğitim-öğretim yılından itibaren dört yıllık yüksek öğretmen okullarına dönüştürülmesi esnasında sosyal bilgiler bölümü kaldırılarak yerine tarih-coğrafya ve coğrafya-tarih bölümleri kurulmuştur (Ercan, 2009). 1982 yılından itibaren yüksek 
öğretmen okullarının eğitim fakültelerine dönüştürülerek üniversitelere devredilmesi sosyal bilgiler öğretmeni yetiştirme usulünde başlangıçta bir değişikliğe neden olmamış ve sosyal bilgiler konu alanını öğretecek öğretmenler sosyal bilimler eğitimi bölümüne bağlı tarih ve coğrafya öğretmenliği anabilim dallarında yetiştirilmeye devam etmişlerdir (YÖK, 2007; Aktaran, Kaymakcı, 2012:46).

Ülkemizde gerek eğitim fakülteleri gerekse sosyal bilgiler öğretmenliği lisans programı için dönüm noktası 1996 yılı olmuştur. Çünkü 1996 yılında sınıf öğretmenlerine duyulan yoğun ihtiyaç sınıf öğretmenliği mezunları tarafından karşılanamamış ve ihtiyaç duyulan sınıf öğretmenliği için ÖSS puanı ile öğrenci kayıt eden fakülte ve yüksekokullar dışındaki örgün yükseköğretim kurumlarından lisans düzeyinde öğretim görmüş olanların müracaatları kabul edilmiştir. 1996 yılı ikinci atama döneminde atamaları yapılan öğretmen adaylarının 3056'sı eğitim fakültesi, 13647'si diğer yükseköğretim kurumu mezunudur. Ayrıca, emekli dönüşü, kurumlar arası nakil ve açıktan olmak üzere 3665 öğretmen ataması yapılmıştır (WEB1). Yine 1997 'de zorunlu ilköğretim süresini 5 yıldan 8 yıla çıkaran 16.08.1997 tarih ve 4306 sayılı kanunla yürürlüğe giren İlköğretim Yasası ile özellikle ilköğretimde öğretmen intiyacı ciddi bir biçimde artmıştır. Biyoloji gibi bazı alanlarda ihtiyaçtan fazla öğretmen varken sınıf öğretmenliği, okul öncesi, İngilizce, sosyal bilgiler öğretmenliği gibi alanlarda ise önemli sayılarda öğretmen eksiği oluşmuştur. (YÖK, 1998:3). 8 yıllık ilköğretimdeki bu eksikleri kapatmak isteyen Yükseköğretim Kurulu Başkanlığı 1996 yılı başında Türkiye'nin gereksinim duyduğu öğretmenleri yetiştirmek üzere eğitim fakülteleri öğretmen yetiştirme programlarının yeniden düzenlenmesi çalışmalarını başlatmış ve buna göre fakültelerdeki lisans ve lisansüstü düzeylerde yürütülen programlarda birtakım değişiklikler yapılmıştır (Kızılçaoğlu,2005). Başta eğitim fakülteleri sayısı arttırılmıştır. 1994-1999 eğitim fakültelerinin sayısı \%50 oranında artmıştır. 1994'de 34 eğitim fakültesi varken, bu sayı 1999'da 51'e yükselmiş ve buna bağlı olarak öğretmen eğitimi programlarında ki öğrenci sayısı da büyük ölçüde artmıştır. Yeni fakültelerin açılmasının yanı sıra artan öğretmen ihtiyacının karşılanması amacıyla eğitim fakültelerine daha fazla öğrenci yerleştirilmesi de öğrenci sayısındaki artışa neden olmuştur (YÖK, 1998; Dursunoğlu, 2003). Bu artışlarla 8 yıllık zorunlu ilköğretim düzeyindeki sınıf öğretmeni ve branş öğretmeni intiyacının karşılanması amaçlanmıştır.

Yüksek Öğretim Kurulu (YÖK) artan öğretmen ihtiyacı için 4 Kasım 1997 tarihli bir kararıyla eğitim fakültelerini yeniden yapılandırdı. Öğretmen eğitimi yeniden düzenlendi. Bu düzenleme, Milli Eğitim Bakanlığı-YÖK ve Dünya Bankasının işbirliği sonucu gerçekleşti. 1997 yılındaki düzenlemeye göre sınıf öğretmenliği kadrolarına, eğitim fakültelerinin ilgili bölümünden mezun elemanlar atanacaklardı. Eğitim fakültelerinde kurulması önerilen ilköğretim bölümünde, okul öncesi eğitimi, sınıf öğretmenliği, fen bilgisi eğitimi, matematik eğitimi ve sosyal bilgiler eğitimi anabilim dalları bulunacaktı. Ayrıca, Türkçe eğitimi bölümü kapsamında Türkçe eğitimi anabilim dalı yer alacaktı. Böylece sadece ilköğretim II. kademeye öğretmen yetiştiren Türkçe öğretmenliği programının, diğer bütün alanlardaki programlara yan alan olarak hizmet vermesi sağlanmaktadır, ilköğretimde branş öğretmenliği kadrosunun oluşturulması 
kuşkusuz önemli bir gelişmedir. Projeye göre ilköğretim branş öğretmenliği programlarındaki alan dersleri bünyesinde Fen-Edebiyat Fakültesi olan üniversitelerde bu fakültelerden alınacaktı. (Aydın, 1998). Yeni programların bir kısmında yan alan uygulamasına yer verilmiştir. Örneğin, ilköğretim II. kademeye öğretmen yetiştirecek olan Türkçe Öğretmenliği için Sosyal Bilgiler, Sosyal Bilgiler Öğretmenliği için Türkçe, Fen Bilgisi Öğretmenliği için Matematik ve Matematik Öğretmenliği için Fen Bilgisi yan alan olarak belirlenmiştir. Yan alan uygulamasına göre, öğretmen adaylarının kendi ana branşları yanında ek bir branşta yetişmeleri öngörülmektedir. Bu şekilde, ihtiyaç duyulduğunda bir öğretmen iki ayrı branş derslerini öğretebilecektir. Özellikle kırsal kesimdeki ilköğretim kurumlarının II. kademesinde bu ihtiyaç Milli Eğitim Bakanlığı tarafından açık olarak belirlenmiştir.

Eğitim Fakültelerinin yeniden yapılandırıması amacıyla 1996 yılında başlatılan çalışmalar, 1998-1999 öğretim yılından itibaren uygulanmaya başlanmıştır. Yeni düzenleme ile birlikte, Eğitim Fakültelerinin büyük çoğunluğunda, ortaöğretim branş öğretmenlikleri kontenjanlarında azaltılmaya gidilmiştir. Buna karşılık ilköğretim okullarına öğretmen yetiştiren Sosyal Bilgiler, Sınıf, Türkçe, Fen Bilgisi ve Matematik Öğretmenlikleri programlarında ise, önemli kontenjan artışları gerçekleştirilmiştir (Özav, 2001: 165).

YÖK'ün 1997 kararı ve eğitim fakültelerinde kurulan sosyal bilgiler anabilim dalları 1997-1998 eğitim-öğretim yılında öğrenci alımına başlamıştır. 1997-1998 yılından önce Sosyal Bilgiler Öğretmenliği lisans programı sadece iki fakültede bulunmaktaydı. Sosyal Bilgiler lisans programı açan ilk fakülte 1993-1994 öğretim yılında ilk öğrenci alımını yapan o zamanki Gazi Üniversitesi'ne bağlı olan Kastomunu Eğitim Fakültesi olurken; onu 1994-1995 öğretim yılında öğrenci alımına başlayan Celal Bayar Üniversitesi Demirci Eğitim Fakültesi takip etmiştir. 1997-1998 yılından itibaren sosyal bilgiler lisans programı öğrenci alımı yapan fakülte sayısı 28'e; 190 olan kontenjan sayısı ise 2950'ye ulaşmış yani 15 kat artış göstermiştir (Özav, 2001: 166; Kaymakcı, 2012; İbret ve Kaymakcı, 2016). 1998-1999 yılında o zamanki öğretmen açığı nedeniyle hem örgün öğretim hem de ikinci öğretim programları açık olan Sosyal Bilgiler öğretmenliği lisans programlarının artan mezun sayısı nedeniyle 2012 yılında itibaren tüm ikinci öğretimler kapatılmış ve sadece örgün eğitim kapsamında öğrenci alımına devam edilmiştir.

Ülkemizde beklenenden daha fazla adayın olduğu bir çok durumda Ölçme, Seçme ve Yerleştirme Merkezi (ÖSYM) sınav yapmaktadır (Gürbüz, Erdem, Temurtaş, Koç, 2015; Açıkgül, Macit ve Çakan, 2015). 1996 yılında yaşanan öğretmen açığı ile 8 yılık zorunlu eğitime geçişle başlayan öğretmen açığını kapatmak için açılan eğitim fakülteleri kısa sürede belirlenen açığı kapatmakla kalmamış talebin üzerinde bir öğretmen adayının eğitim fakültesinden mezun olmasına neden olmuştur. Belirlenen ihtiyacın yaklaşık 5 katı adayın eğitim fakültesinden mezun olmasıyla birlikte eğitim fakültesinden mezun öğretmenlik mezunlarına Kamu Personeli Seçme Sınavı ya da kısaca KPSS, 18/3/2002 tarih ve 2002/3975 sayılı Bakanlar Kurulu Kararı'na istinaden ilk olarak 2002 yılında ÖSYM tarafından hazırlanıp, uygulanmaya konmuştur. 1999 yılında Kamu Personeli Yasası'nda yapılan düzenleme ile daha önce DMS adı ile 
uygulanan sınav, bu tarihten itibaren KMS olarak isim ve nitelik değiştirmiştir. Türkiye'de ilk DMS ( Devlet Memurluk Sınavı ) 1999 yılında yapıldı ve bu sınav dört farklı düzeyde yapıldı. Bu düzeyler:

A Düzeyi: Lisans (dört ve daha fazla yıllık yükseköğretim) programlarından mezun olan adaylar

B Düzeyi: Önlisans (iki yıllık meslek yüksekokulu) programlarından mezun olanlar

C Düzeyi: Ortaöğretimden (lise ve dengi okul) mezun olanlar

D Düzeyi: İlköğretim (ortaokul) mezunları

DMS formatında yapılan bu sınav daha çok kamuda 657 tabi düz memurluk pozisyonlarında çalışmak isteyenler içindi. Daha sonra Kamu Personel Yasası çerçevesinde yapılan değişikliklerle beraber yapılan eleme sınavının kapsamı daha da genişletilerek 4 oturumdan oluşan öğretmenlik, düz memurluk, sözleşmeli personel ve kariyer meslekleri için olan yaklaşık 120 puan türünün yer aldığı bir ön eleme sınavı haline getirilerek 2001 tarihinde Kurumlar İçin Merkezi Eleme Sınavı (KMS) adı altında yapılmaya başlandı.120 puan türü ve 4 farklı oturumunda oluşan sınav; öğretmenlik, sözleşmeli personel, memurluk ve uzman kadroların istihdamında eleme sınavı niteliği taşımaktaydı. KMS sadece ilk ve son defa 7-8 Temmuz 2001 tarihinde uygulanmıştır. Bir sonraki yıl olan 2002'de ise sınav, yapılan isim değişikliği ile KPSS adını almış ve aynı yılın 6-7 Temmuz tarihlerinde ilk defa adaylara uygulanmıştır. Devam eden senelerde KPSS, kamu kurum ve kuruluşlarının istek ve ihtiyaçları doğrultusunda şekillenerek temel olarak 2 farklı sınav ve 3 farklı gruba ayrılmıştır. Sınavlar farklı tarihlerde ve farklı niteliğe sahip adaylara uygulanmaktadır. 2013 yılında ÖSYM tarafından öğretmenlik adaylarına bazı branşlara yönelik olarak ilk defa Öğretmenlik Alan Bilgisi Testi (ÖABT) sınavı da uygulanmaya başlanmıştır (WEB2).

Öğretmen açığını kapatmak için başlayan eğitim fakültesi sayısı ve öğrenci sayısındaki artış gitgide karmaşık bir vaziyet almış; fen-edebiyatlara verilen sınırı sayıdaki formasyonun tüm mezunlara tanınması ile birlikte öğretmenlik alanında sınava giren aday sayısında patlama yaşanmıştır. 2017 ÖSYM verilerine göre 434102 aday öğretmen adayı olmak için eğitim bilimleri testi sınavına başvurmuş, bunların 412.185'i sınava girmiştir. Bu adaylardan 308.125'i ise ÖABT sınavına başvurmuş ve 265.646'sı ÖABT sınavına girmiştir (WEB3). Yine Safran, Kan, Üstündağ, Birbudak ve Yıldırım'ın (2014) yaptığı çalışmaya istinaden eğitim fakültesindeki yaklaşık 220.000, Fen-edebiyat fakültelerinde öğrenim gören 280.000 ilahiyat fakültesi, güzel sanatlar, iletişim, beden eğitimi spor yüksekokulları gibi pedagojik formasyon hakkı tanınan tüm fakültelerde öğrenim gören 734.000 ve atanmayı bekleyen 300.000 kişi düşünüldüğünde şu an Türkiye'de 1000.000'e yakın kişinin gelecek yıllarda öğretmen olmak için sırada beklediği belirtmektedir. Bu kadar fazla kişinin öğretmen olmak için beklediği bir yerde maalesef talebin bunun çok altında olduğu ve önlem alınmazsa bu sorunun gitgide daha grift hale geleceği aşikardır. 
$\mathrm{Bu}$ araştırmada Türkiye üniversitelerinde sosyal bilgiler öğretmenliği anabilim dallarının mevcut durumu (2017) ortaya konularak geleceğe yönelik bir perspektif çizilmesine yardım etmek amaçlanmıştır.

Araştırma sonucunda şu sorulara cevap aranmıştır:

1. Türkiye'deki sosyal bilgiler öğretmenliği anabilim dallarının öğrenci alımına başladığı yıllar hangileridir.

2. Aktif öğrencisi bulunan sosyal bilgiler öğretmenliği anabilim dalları ve öğrenci sayıları

3. Sosyal bilgiler öğretmenliği anabilim dalına yerleşen öğrencilerin alt ve üst puan sıraları (2013-2017)

4. 2017 yılı itibariyle Sosyal bilgiler eğitimi anabilim dalında bulunan öğretim elemanı sayısı ne kadardır?

5. Sosyal bilgiler öğretmenliğine ait atama sayları (2013-2017) nasıldır?

6. 2016 KPSS ÖABT sınavına giren branşlar, bunların test ortalaması, sınava giren aday sayısı ve 2017 atanma sayısı oranları nelerdir?

\section{Yöntem}

Araştırma verileri nitel araştırma yöntemlerinden doküman incelemesi yoluyla toplanmıştır. Doküman incelemesi, araştırılması hedeflenen olgu ya da olgular hakkında bilgi içeren yazılı materyallerin analizini kapsamaktadır. Doküman incelemesi, bir araştırma problemi hakkında belirli zaman dilimi içerisinde üretilen dokümanlar ya da ilgili konuda birden fazla kaynak tarafından ve değişik aralıklarla üretilmiş dokümanların geniş bir zaman dilimine dayalı analizini olanaklı kılmaktadır (Yıldırım ve Şimşek, 2000:140-143).

\section{Veri Kaynağı- Verilerin Toplanması ve Analizi}

Araştırmada veri toplama aracı olarak faaliyettte olan sosyal bilgiler anabilim dallarının öğrenci sayılarının ve anabilim dalı taban puanlarının belirlenmesinde ise son 4 yılın ÖSYM kılavuzunda yer alan bilgiler kullanılmıştır. Bu bilgiler https://yokatlas.yok.gov.tr/ 'den (WEB4) temin edilmiştr. Yine sosyal bilgiler ve diğer branşlara ait verilerin toplanmasında ise https://dokuman.osym.gov.tr/ adresindeki verilerden yararlanılmıştır. Anabilim dallarının faaliyet yılı ve görev yapan öğretim üyesi sayısı için ise anabilim dallarının internet sayfalarında yer alan bilgiler kullanılmıştır. İlgili anabilim dallarının İnternet sayfalarında istenilen bilgilere ulaşılamadığı durumlarda anabilim dalında yer alan öğretim üyeleri ile temasa geçilerek gerekli bilgiler alınmıştır. Elde edilen veriler tablolara dönüştürülerek araştırmanın bulgular bölümünde değerlendirilmiştir.

\section{Bulgular}

Araştırmanın bu bölümünde araştırma sorularına bağlı olarak; Türkiye'deki sosyal bilgiler öğretmenliği anabilim dallarının öğrenci alımına başladığı yıllar, aktif öğrencisi bulunan sosyal bilgiler öğretmenliği anabilim dalları ve öğrenci sayıları, sosyal bilgiler 
öğretmenliği anabilim dalına yerleşen öğrencilerin alt ve üst puan sıraları (2013-2017), sosyal bilgiler öğretmenliği anabilim dalına kayıt yaptıran en düşük puanlı öğrencilerin LYS sırası (2013-2016), üniversitelerin eğitim fakülteleri sosyal bilgiler öğretmenliği lisans programında görevli eleman sayıları, sosyal bilgiler öğretmenliğine ait atama sayıları (2013-2017), 2016 KPSS ÖABT sınavına giren branşlar, bunların test ortalaması, sınava giren aday sayısı ve 2017 atanma sayısı oranlarına yer verilmiştir

Tablo 1: Türkiye'deki sosyal bilgiler öğretmenliği anabilim dallarının öğrenci alımına başladığı yıllar

\begin{tabular}{|c|c|c|}
\hline \multicolumn{2}{|r|}{ Üniversite Adı } & \multirow{2}{*}{$\begin{array}{r}\text { Öğrenci Alımına Başladığı Yıl } \\
2002-2003\end{array}$} \\
\hline 1 & Adıyaman & \\
\hline 2 & Adnan Menderes & 2004-2005 \\
\hline 3 & Afyon Kocatepe & 2001-2002 \\
\hline 4 & Ağrı İbrahim Çeçen & 2001-2002 \\
\hline 5 & Akdeniz & 2009-2010 \\
\hline 6 & Aksaray & 2008-2009 \\
\hline 7 & Amasya & 1998-1999 \\
\hline 8 & Anadolu & 1998-1999 \\
\hline 9 & Ankara & 1998-1999 \\
\hline 10 & Artvin Çoruh & 2011-2012 \\
\hline 11 & Atatürk & 1998-1999 \\
\hline 12 & Balıkesir & 1998-1999 \\
\hline 13 & Bartın & $2012-2013$ \\
\hline 14 & Bayburt & 2016-2017 \\
\hline 15 & Bolu Abant İzzet Baysal & 1998-1999 \\
\hline 16 & Bozok & 2016-2017 \\
\hline 17 & Bülent Ecevit & 1998-1999 \\
\hline 18 & Celal Bayar & 1994-1995 \\
\hline 19 & Cumhuriyet & 1998-1999 \\
\hline 20 & Çanakkale 18 Mart & $\begin{array}{r}1998-1999 / \\
2008-2011 \text { öğrenci alımı yok } \\
\end{array}$ \\
\hline 21 & Çukurova & 1998-1999 \\
\hline 22 & Dicle & 1998-1999 \\
\hline 23 & Dokuz Eylül & 1998-1999 \\
\hline 24 & Ege & $2009-2010$ \\
\hline 25 & Erciyes & $2002-2003$ \\
\hline 26 & Erzincan & 1998-1999 \\
\hline 27 & Firat & 2001-2002 \\
\hline 28 & Gazi Eğitim Fakültesi & 1998-1999 \\
\hline 29 & Gaziantep (Nizip Eğitim Fak.) & 2012-2013 \\
\hline 30 & Giresun & 1998-1999 \\
\hline 31 & İnönü & 1998-1999 \\
\hline 32 & İstanbul & 1998-1999 \\
\hline 33 & Kafkas & $2002-2003$ \\
\hline 34 & Karadeniz Teknik (2018 yılından itibaren adı Trabzon) & 1998-1999 \\
\hline 35 & $\begin{array}{l}\text { Kastamonu } \\
\text { (2006 yılında Gazi Üniversitesinden ayrıldı) }\end{array}$ & 1993-1994 \\
\hline 36 & Kırıkkale & 2013-2014 \\
\hline 37 & $\begin{array}{l}\text { Kırşehir Ahi Evran } \\
\text { (2006 yılında Gazi Üniversitesinden ayrıldı) }\end{array}$ & 1998-1999 \\
\hline 38 & Kilis 7 Aralık & $2002-2003$ \\
\hline 39 & Kütahya Dumlupınar & $2004-2005$ \\
\hline
\end{tabular}


Tablo 1'in devamı

\begin{tabular}{llr}
\hline $\mathbf{4 0}$ & Marmara & $1998-1999$ \\
\hline $\mathbf{4 1}$ & Mehmet Akif Ersoy & $1998-1999$ \\
\hline $\mathbf{4 2}$ & Muğla Sıtkı Koçman & $2001-2002$ \\
\hline $\mathbf{4 3}$ & Muş Alparslan & $2010-2011$ \\
\hline $\mathbf{4 4}$ & Necmettin Erbakan & $1998-1999$ \\
& (2010 yılına kadar Selçuk; 2010 yılı Konya Üniversitesi) & $2014-2015$ \\
\hline $\mathbf{4 5}$ & Nevşehir Hacı Bektaş Veli & $1998-1999$ \\
\hline $\mathbf{4 6}$ & Niğde Ömer Halisdemir & $1998-1999$ \\
\hline $\mathbf{4 7}$ & Ondokuz Mayıs & $1998-1999$ \\
\hline $\mathbf{4 8}$ & Pamukkale & $2010-2011$ \\
\hline $\mathbf{4 9}$ & Recep Tayyip Erdoğan & $1998-1999$ \\
\hline $\mathbf{5 0}$ & Sakarya & $1998-1999$ \\
\hline $\mathbf{5 1}$ & Siirt & $2003-2004$ \\
\hline $\mathbf{5 2}$ & Sinop & $2013-2014$ \\
\hline $\mathbf{5 3}$ & Süleyman Demirel & $2002-2003$ \\
\hline $\mathbf{5 4}$ & Tokat Gaziosmanpaşa & $2007-2008$ \\
\hline $\mathbf{5 5}$ & Trakya & $2008-2009$ \\
\hline $\mathbf{5 6}$ & Uludağ & $2000-2001$ \\
\hline $\mathbf{5 7}$ & Uşak & $1998-1999$ \\
\hline $\mathbf{5 8}$ & Van Yüzüncü Yıl & $2010-2011$ \\
\hline $\mathbf{5 9}$ & Yıldız Teknik &
\end{tabular}

Türkiye'deki sosyal bilgiler öğretmenliği anabilim dallarının öğrenci alımına başladığı yıllar Tablo 1'de verilmiştir. Tablo 1'e göre Türkiye üniversitelerinde 59 sosyal bilgiler öğretmenliği anabilim dalı bulunmaktadır. 1997-1998 yılından önce sadece iki fakülte (Gazi Üniversitesi'ne bağlı bir fakülte olan Kastamonu Eğitim Fakültesi ve Celal Bayar Üniversitesi Demirci Eğitim Fakültesi) sosyal bilgiler öğretmenliği lisans programına öğrenci alımı yaparken; bu sayı 1998-1999 eğitim-öğretim yılında yani YÖK'ün eğitim fakültelerini tekrar yapılandırdığı yılda 28'e; 2017 yılında ise 59'a yükselmiştir. Sosyal bilgiler öğretmenliği anabilim dallarının 2012'den bu yana sadece örgün öğretim öğrencisi bulunmakta, hiçbir programda ikinci öğretim faaliyeti yürütülmemektedir.

Tablo 2: Aktif öğrencisi bulunan sosyal bilgiler öğretmenliği anabilim dalları ve öğrenci sayıları

\begin{tabular}{|c|c|c|c|c|c|c|}
\hline & & 2016 & 2015 & 2014 & 2013 & \\
\hline & Üniversite Adı & 1.sınıf & 2.sınıf & 3.sınıf & 4.sınıf & Toplam \\
\hline 1 & Adıyaman & 62 & 62 & 62 & 62 & 248 \\
\hline 2 & Adnan Menderes & 62 & 62 & 62 & 62 & 248 \\
\hline 3 & Afyon Kocatepe & 88 & 88 & 88 & 88 & 352 \\
\hline 4 & Ağrı İbrahim Çeçen & 93 & 93 & 93 & 88 & 367 \\
\hline 5 & Akdeniz & 82 & 82 & 82 & 82 & 328 \\
\hline 6 & Aksaray & 52 & 52 & 52 & 52 & 208 \\
\hline 7 & Amasya & 62 & 62 & 62 & 62 & 248 \\
\hline 8 & Anadolu & 62 & 62 & 62 & 62 & 248 \\
\hline 9 & Ankara & 62 & 62 & 62 & 62 & 248 \\
\hline 10 & Artvin Çoruh & 57 & 57 & 57 & 57 & 228 \\
\hline 11 & Atatürk & 93 & 93 & 93 & 93 & 372 \\
\hline 12 & Balıkesir & 62 & 62 & 62 & 62 & 248 \\
\hline 13 & Bartın & 52 & 47 & 47 & 47 & 193 \\
\hline 14 & Bayburt & 31 & ---- & ---- & ---- & 31 \\
\hline
\end{tabular}


Tablo 2'nin devamı

\begin{tabular}{|c|c|c|c|c|c|c|}
\hline 15 & Bolu Abant İzzet Baysal & 72 & 72 & 72 & 72 & 288 \\
\hline 16 & Bozok & 41 & ---- & ---- & ---- & 41 \\
\hline 17 & Bülent Ecevit & 57 & 57 & 57 & 57 & 228 \\
\hline 18 & Celal Bayar & 93 & 93 & 93 & 93 & 372 \\
\hline 19 & Cumhuriyet & 93 & 93 & 93 & 93 & 372 \\
\hline 20 & Çanakkale 18 Mart & 47 & 47 & 47 & 47 & 188 \\
\hline 21 & Çukurova & 52 & 52 & 52 & 52 & 208 \\
\hline 22 & Dicle & 88 & 88 & 88 & 88 & 352 \\
\hline 23 & Dokuz Eylül & 93 & 93 & 93 & 93 & 372 \\
\hline 24 & Ege & 62 & 62 & 62 & 62 & 248 \\
\hline 25 & Erciyes & 72 & 72 & 72 & 72 & 288 \\
\hline 26 & Erzincan & 93 & 93 & 93 & 93 & 372 \\
\hline 27 & Firat & 62 & 62 & 62 & 62 & 248 \\
\hline 28 & Gazi & 93 & 93 & 93 & 93 & 372 \\
\hline 29 & Gaziantep & 52 & 52 & 52 & 52 & 208 \\
\hline 30 & Giresun & 88 & 88 & 88 & 88 & 352 \\
\hline 31 & İnönü & 62 & 62 & 62 & 62 & 248 \\
\hline 32 & İstanbul & 57 & 57 & 57 & 57 & 228 \\
\hline 33 & Kafkas & 62 & 62 & 62 & 62 & 248 \\
\hline 34 & $\begin{array}{l}\text { Karadeniz Teknik ( } 2018 \text { yılından } \\
\text { itibaren adı Trabzon) }\end{array}$ & 93 & 93 & 93 & 93 & 372 \\
\hline 35 & Kastamonu & 93 & 93 & 93 & 93 & 372 \\
\hline 36 & Kırıkkale & 52 & 52 & ---- & --- & 104 \\
\hline 37 & Kırşehir Ahi Evran & 82 & 82 & 82 & 82 & 328 \\
\hline 38 & Kilis 7 Aralık & 62 & 62 & 62 & 62 & 248 \\
\hline 39 & Kütahya Dumlupınar & 72 & 72 & 72 & 72 & 288 \\
\hline 40 & Marmara & 72 & 72 & 72 & 72 & 288 \\
\hline 41 & Mehmet Akif Ersoy & 62 & 62 & 62 & 62 & 248 \\
\hline 42 & Muğla Sıtkı Koçman & 72 & 72 & 72 & 72 & 288 \\
\hline 43 & Muş Alparslan & 52 & 52 & 52 & 52 & 208 \\
\hline 44 & Necmettin Erbakan & 93 & 93 & 93 & 93 & 372 \\
\hline 45 & Nevşehir Hacı Bektaş Veli & 41 & 41 & 41 & --- & 123 \\
\hline 46 & Niğde Ömer Halisdemir & 93 & 93 & 93 & 93 & 372 \\
\hline 47 & Ondokuz Mayıs & 57 & 57 & 57 & 57 & 228 \\
\hline 48 & Pamukkale & 93 & 93 & 93 & 93 & 372 \\
\hline 49 & Recep Tayyip Erdoğan & 67 & 67 & 67 & 67 & 268 \\
\hline 50 & Sakarya & 62 & 62 & 62 & 62 & 248 \\
\hline 51 & Siirt & 93 & 93 & 93 & 93 & 372 \\
\hline 52 & Sinop & 62 & 62 & 62 & 62 & 248 \\
\hline 53 & Süleyman Demirel & 31 & 31 & 31 & 31 & 124 \\
\hline 54 & Tokat Gaziosmanpaşa & 62 & 62 & 62 & 62 & 248 \\
\hline 55 & Trakya & 62 & 62 & 62 & 62 & 248 \\
\hline 56 & Uludağ & 47 & 47 & 47 & 47 & 188 \\
\hline 57 & Uşak & 62 & 62 & 62 & 62 & 248 \\
\hline 58 & Van Yüzüncü Yıl & 62 & 62 & 62 & 62 & 248 \\
\hline \multirow[t]{2}{*}{59} & Yıldız Teknik & 47 & 47 & 47 & 47 & 188 \\
\hline & Toplam & 4005 & 3928 & 3876 & 3830 & 15.639 \\
\hline
\end{tabular}

Tablo 2'den aktif öğrencisi bulunan sosyal bilgiler öğretmenliği öğrenci sayıları incelendiğinde LYS kontenjanları esas alındığında toplam öğrenci sayısı 15.639'dur. 
59 üniversite içerisinde öğrenci sayısı en fazla olan üniversiteler 372 öğrenci ile Atatürk, Celal Bayar, Cumhuriyet, Dokuz Eylül, Erzincan, Gazi, Karadeniz Teknik (2018 yılından itibaren adı Trabzon), Kastamonu, Necmettin Erbakan, Niğde Ömer Halisdemir, Pamukkale ve Siirt Üniversiteleridir. 1-2-3-4 sınıfında öğrencisi bulunan üniversiteler içerisinde en az öğrencisi olan üniversite ise 31 öğrenci ile Bayburt, 41 öğrenci ile Bozok Üniversitesidir. Bunun nedeni ise Bayburt ve Bozok Üniversitesi'nde sosyal bilgiler öğretmenliği anabilim dalının 2016-2017 öğretim yılında öğrenci alımına başlamış olmasıdır.

Tablo 3: Sosyal bilgiler öğretmenliği anabilim dalına yerleşen öğrencilerin alt ve üst puan sıraları (2013-2016)

\begin{tabular}{rcccc}
\hline Sıra & 2016 & 2015 & 2014 & 2013 \\
\hline En Büyük & 25.800 (İstanbul Ü.) & 17.700 (İstanbul Ü.) & 10.200 (Istanbul Ü.) & 7.140 (İstanbul Ü.) \\
\hline En Küçük & 75.900 (Bartın Ü.) & 56.300 (Kafkas Ü.) & 41.900 (Bülent Ecevit Ü.) & 28.200 (Kafkas Ü.) \\
\hline
\end{tabular}

Kaynak:WEB4

Yıllara göre (2013-2016) sosyal bilgiler öğretmenliği anabilim dallarına yerleşen öğrencilerin LYS puanlarının üst ve alt sıraları tablo 3'te verilmiştir. Buna göre sosyal bilgiler öğretmenliği programının puan sıralarının oldukça değişken olduğu görülmektedir. 2016 yılında sosyal bilgiler öğretmenliği programına yerleşen en yüksek puanlı öğrencinin puan sırası 25.800 iken en düşük puanlı öğrencinin sırası 75.900'dür. Son dört yıl içinde sosyal bilgiler öğretmenliği anabilim dalını tercih eden en yüksek puanlı öğrencinin sırası 2013 yılında görülen 7.140’tır. 2013-2016 yılı verilerine göre sosyal bilgiler öğretmenliği anabilim dallarına yerleşen en yüksek puanlı öğrencilerin tercih ettikleri üniversite İstanbul Üniversitesi'dir. Öğrencilerin ikinci ve üçüncü tercih ettikleri iki üniversite değişimli olarak Marmara ve Yıldız Teknik Üniversiteleri'dir. Dördüncü ve beşinci sırada Ankara ve Ege Üniversitesi yer almaktadır.

Tablo 4: Sosyal bilgiler öğretmenliği anabilim dalına kayıt yaptıran en düşük puanlı öğrencilerin LYS sırası (2013-2016)

\begin{tabular}{|c|c|c|c|c|c|c|c|c|}
\hline & Üniversite Adı & 2016 & Üniversite Adı & 2015 & Üniversite Adı & 2014 & Üniversite Adı & 2013 \\
\hline 1 & İstanbul & 25.800 & İstanbul & 17.700 & İstanbul & 10.200 & İstanbul & 7.140 \\
\hline 2 & Yıldız Teknik & 31.700 & Yıldız Teknik & 17.700 & Marmara & 13.200 & Marmara & 9.730 \\
\hline 3 & Marmara & 33.800 & Marmara & 21.200 & Yıldız Teknik & 15.400 & Yıldız Teknik & 10.700 \\
\hline 4 & Ankara & 34.000 & Ege & 21.600 & Ankara & 16.000 & Ege & 11.500 \\
\hline 5 & Ege & 35.400 & Ankara & 24.700 & Ege & 16.900 & Ankara & 12.000 \\
\hline 6 & Gazi & 36.600 & Gazi & 24.800 & Uludağ & 19.100 & Çukurova & 14.200 \\
\hline 7 & Uludağ & 36.700 & Uludağ & 27.300 & Gazi & 19.200 & Gazi & 14.400 \\
\hline 8 & Anadolu & 38.500 & Anadolu & 27.400 & Çukurova & 19.700 & Dokuz Eylül & 14.500 \\
\hline 9 & Dokuz Eylül & 39.600 & Çukurova & 27.600 & Dicle & 20.700 & Uludağ & 14.500 \\
\hline 10 & Çukurova & 40.200 & Dokuz Eylül & 28.000 & Anadolu & 21.400 & Anadolu & 14.900 \\
\hline 11 & Erciyes & 43.400 & Akdeniz & 30.100 & Dokuz Eylül & 21.900 & Akdeniz & 16.700 \\
\hline 12 & Akdeniz & 43.700 & Erciyes & 32.100 & Erciyes & 24.100 & Dicle & 16.900 \\
\hline 13 & İnönü & 45.800 & Sakarya & 32.500 & Ondokuz Mayıs & 24.200 & Ondokuz Mayıs & 16.900 \\
\hline 14 & Dicle & 47.600 & Dicle & 33.000 & Akdeniz & 24.400 & Erciyes & 18.300 \\
\hline 15 & Ondokuz Mayıs & 47.800 & İnönü & 33.000 & İnönü & 24.400 & Onsekiz Mart & 18.400 \\
\hline 16 & Onsekiz Mart & 48.600 & Onsekiz Mart & 33.400 & Onsekiz Mart & 25.400 & İnönü & 18.400 \\
\hline 17 & Sakarya & 48.800 & Ondokuz Mayıs & 33.700 & Necmettin Er. & 26.400 & Necmettin Er. & 18.500 \\
\hline
\end{tabular}


Tablo 4'ün devamı

\begin{tabular}{|c|c|c|c|c|c|c|c|c|}
\hline 18 & $\begin{array}{l}\text { Necmettin } \\
\text { Erbakan }\end{array}$ & 48.900 & $\begin{array}{l}\text { Necmettin } \\
\text { Erbakan }\end{array}$ & 34.800 & Van Yüzüncü Yıl & 26.600 & Balıkesir & 18.800 \\
\hline 19 & Gaziantep & 50.700 & \begin{tabular}{lc|}
$\begin{array}{l}\text { Muğla } \\
\text { Koçman }\end{array}$ & Sıtkı \\
\end{tabular} & 35.300 & $\begin{array}{l}\text { Süleyman } \\
\text { Demirel }\end{array}$ & 27.200 & Sakarya & 19.000 \\
\hline 20 & $\begin{array}{l}\text { Muğla Sıtkı } \\
\text { Koçman }\end{array}$ & 51.000 & Balıkesir & 36.800 & Sakarya & 27.900 & $\begin{array}{l}\text { Muğla } \\
\text { Koçman }\end{array}$ & 19.500 \\
\hline 21 & Firat & 51.800 & $\begin{array}{l}\text { Adnan } \\
\text { Menderes }\end{array}$ & 37.200 & Fırat & 28.000 & $\begin{array}{l}\text { Adnan } \\
\text { Menderes }\end{array}$ & 19.700 \\
\hline 22 & $\begin{array}{l}\text { Van Yüzüncü } \\
\text { Yıl }\end{array}$ & 51.900 & $\begin{array}{l}\text { Süleyman } \\
\text { Demirel }\end{array}$ & 37.200 & Gaziantep & 28.200 & Pamukkale & 20.100 \\
\hline 23 & $\begin{array}{l}\text { Karadeniz Teknik } \\
\text { (Trabzon) }\end{array}$ & 53.600 & $\begin{array}{l}\text { Bolu Abant Izzet } \\
\text { Baysal }\end{array}$ & 37.500 & Adıyaman & 29.900 & $\begin{array}{l}\text { Bolu Abant İzet } \\
\text { Baysal }\end{array}$ & 20.200 \\
\hline 24 & Balıkesir & 54.200 & Pamukkale & 38.300 & $\begin{array}{l}\text { MuğlaSıtkı } \\
\text { Koçman }\end{array}$ & 30.500 & Firat & 21.100 \\
\hline 25 & Adivaman & 54.600 & Gaziantep & 38.500 & Balıkesir & 30.800 & $\begin{array}{l}\text { Karadeniz Teknik } \\
\text { (Trabzon) }\end{array}$ & 21.600 \\
\hline 26 & $\begin{array}{l}\text { Adnan } \\
\text { Menderes }\end{array}$ & 55.200 & Firat & 38.900 & $\begin{array}{l}\text { Adnan } \\
\text { Menderes }\end{array}$ & 32.000 & Trakya & 21.700 \\
\hline 27 & Pamukkale & 57.200 & Van Yüzüncü Yıl & 38.900 & $\begin{array}{l}\text { Bolu Abant Izzet } \\
\text { Baysal }\end{array}$ & 32.100 & Gaziantep & 21.800 \\
\hline 28 & $\begin{array}{l}\text { Bolu Abant İzzet } \\
\text { Baysal }\end{array}$ & 58.400 & Adıyaman & 39.600 & Pamukkale & 32.400 & Celal Bayar & 22.100 \\
\hline 29 & $\begin{array}{l}\text { Süleyman } \\
\text { Demirel }\end{array}$ & 58.800 & Trakya & 39.800 & Amasya & 34.100 & Adıyaman & 22.200 \\
\hline 30 & Atatürk & 59.200 & $\begin{array}{l}\text { Karadeniz } \\
\text { Teknik(Trabzon) }\end{array}$ & 40.200 & Siirt & 34.300 & Van Yüzüncü Yıl & 22.400 \\
\hline 31 & Kırıkkale & 60.000 & Kırıkkale & 41.400 & $\begin{array}{l}\text { Karadeniz Teknik } \\
\text { (Trabzon) }\end{array}$ & 34.700 & $\begin{array}{l}\text { Kütahya } \\
\text { Dumlupınar }\end{array}$ & 22.600 \\
\hline 32 & $\begin{array}{l}\text { Nevşehir Hacı } \\
\text { Bektaş Veli }\end{array}$ & 60.700 & $\begin{array}{l}\text { Nevşehir Hacı } \\
\text { Bektaş Veli }\end{array}$ & 42.200 & Trakya & 34.900 & Amasya & 23.600 \\
\hline 33 & Trakya & 62.000 & Amasya & 42.400 & Kilis 7 Aralık & 35.700 & Afyon Kocatepe & 23.700 \\
\hline 34 & Aksarav & 63.100 & $\begin{array}{l}\text { Kütahya } \\
\text { Dumluoınar }\end{array}$ & 43.200 & Celal Bayar & 36.200 & Atatürk & 23.700 \\
\hline 35 & Cumhuriyet & 63.100 & Celal Bayar & 44.100 & $\begin{array}{l}\text { Ağrı İbrahim } \\
\text { Çeçen }\end{array}$ & 36.600 & Kilis 7 Aralık & 24.100 \\
\hline 36 & Kafkas & 63.400 & Kilis 7 Aralık & 44.300 & $\begin{array}{l}\text { Kütahya } \\
\text { Dumlupınar }\end{array}$ & 37.100 & Aksaray & 24.300 \\
\hline 37 & Muş Alparslan & 64.700 & Atatürk & 45.700 & Muş Alparslan & 37.200 & $\begin{array}{l}\text { Mehmet } \\
\text { Ersoy }\end{array}$ & 24.400 \\
\hline 38 & Kilis 7 Aralık & 65.200 & $\begin{array}{l}\text { Niğde Ömer } \\
\text { Halisdemir }\end{array}$ & 45.900 & Atatürk & 37.500 & Bülent Ecevit & 24.600 \\
\hline 39 & Celal Bayar & 65.700 & Bülent Ecevit & 46.100 & $\begin{array}{l}\text { Kırşehir } \\
\text { Evran }\end{array}$ & 37.600 & $\begin{array}{l}\text { Niğde Ömer } \\
\text { Halisdemir }\end{array}$ & 24.600 \\
\hline 40 & $\begin{array}{l}\text { Kütahya } \\
\text { Dumlupınar }\end{array}$ & 5.700 & Afyon Kocatepe & 46.300 & Kafkas & 37.600 & Uşak & 24.700 \\
\hline 41 & Amasya & 66.500 & Siirt & 46.800 & $\begin{array}{l}\text { Recep Tayyip } \\
\text { Erdoğan }\end{array}$ & 7.900 & $\begin{array}{l}\text { Kırşehir } \\
\text { Evran }\end{array}$ & 25.200 \\
\hline 42 & Afyon Kocatepe & 66.900 & Uşak & 47.200 & Aksaray & 38.000 & Siirt & 25.200 \\
\hline 43 & $\begin{array}{l}\text { Mehmet Akif } \\
\text { Ersoy }\end{array}$ & 66.900 & Aksaray & 47.400 & Erzincan & 38.200 & Cumhuriyet & 25.300 \\
\hline 44 & $\begin{array}{l}\text { Recep Tayyip } \\
\text { Erdoğan }\end{array}$ & 67.200 & Cumhuriyet & 47.800 & Afyon Kocatepe & 38.600 & $\begin{array}{l}\text { Tokat } \\
\text { Gaziosmanpaşa }\end{array}$ & 26.100 \\
\hline 45 & Giresun & 68.200 & $\begin{array}{l}\text { Tokat } \\
\text { Gaziosmanpaşa }\end{array}$ & 48.200 & $\begin{array}{l}\text { Mehmet Akif } \\
\text { Ersoy }\end{array}$ & 39.200 & Kastamonu & 26.300 \\
\hline 46 & Artvin Çoruh & 68.400 & Bartın & 48.200 & $\begin{array}{l}\text { Niğde Ömer } \\
\text { Halisdemir }\end{array}$ & 39.200 & Muş Alparslan & 26.400 \\
\hline 47 & Siirt & 68.900 & $\begin{array}{l}\text { Mehmet Akif } \\
\text { Ersoy }\end{array}$ & 48.400 & Artvin Çoruh & 39.300 & Bartın & 26.500 \\
\hline 48 & $\begin{array}{l}\text { Niğde Ömer } \\
\text { Halisdemir }\end{array}$ & 69.500 & $\begin{array}{ll}\text { Kırşehir } & \text { Ahi } \\
\text { Evran }\end{array}$ & 48.600 & Uşak & 39.600 & Giresun & 26.500 \\
\hline 49 & Erzincan & 69.900 & $\begin{array}{l}\text { Recep Tayyip } \\
\text { Erdoğan }\end{array}$ & 49.200 & Cumhuriyet & 39.700 & Sinop & 26.500 \\
\hline 50 & Uşak & 70.200 & Sinop & 49.400 & Giresun & 40.000 & $\begin{array}{l}\text { Recep Tayyip } \\
\text { Erdoğan }\end{array}$ & 26.600 \\
\hline
\end{tabular}


Tablo 4'ün devamı

\begin{tabular}{|c|c|c|c|c|c|c|c|c|}
\hline 51 & Kastamonu & 70.400 & Kastamonu & 50.300 & $\begin{array}{l}\text { Tokat } \\
\text { Gaziosmanpaşa }\end{array}$ & 40.000 & Erzincan & 27200 \\
\hline 52 & $\begin{array}{l}\text { Kırşehir Ahi } \\
\text { Evran }\end{array}$ & 70.500 & Giresun & 50.400 & Bartın & 40.700 & Artvin Çoruh & 27.800 \\
\hline 53 & $\begin{array}{l}\text { Ağrı İbrahim } \\
\text { Çeçen }\end{array}$ & 71.100 & Muş Alparslan & 52.300 & Kastamonu & 41.200 & $\begin{array}{ll}\text { Ağrı İbrahim } \\
\text { Çeçen }\end{array}$ & 28.000 \\
\hline 54 & Bülent Ecevit & 72.600 & Erzincan & 53.600 & Sinop & 41.300 & Kafkas & 28.200 \\
\hline 55 & $\begin{array}{l}\text { Tokat } \\
\text { Gaziosmanpaşa }\end{array}$ & 72.600 & $\begin{array}{ll}\text { Ağrı } & \text { İbrahim } \\
\text { Çeçen } & \\
\end{array}$ & 53.800 & Bülent Ecevit & 41.900 & $\begin{array}{l}\text { Süleyman } \\
\text { Demirel }\end{array}$ & ----- \\
\hline 56 & Sinop & 73.700 & Artvin Çoruh & 56.000 & Kırıkkale & - & & \\
\hline 57 & Bartın & 75.900 & Kafkas & 56.300 & $\begin{array}{l}\text { Nevşehir } \mathrm{HaCl} \\
\text { Bektaş Veli }\end{array}$ & - & & \\
\hline 58 & Yozgat Bozok & - & & & & & & \\
\hline 59 & Bayburt & - & & & & & & \\
\hline
\end{tabular}

Tablo 4'den sosyal bilgiler eğitimi anabilim dallarına kayıt yaptıran en küçük puanlı öğrencilerin LYS sırası incelendiğinde sosyal bilgiler eğitimi anabilim dalına yerleşen öğretmen adaylarının LYS puan sıraları arasındaki büyük fark dikkat çekmektedir. 2013-2016 yılı verilerine göre sosyal bilgiler eğitimi anabilim dallarına yerleşen en yüksek puanlı öğrencilerin tercih ettikleri üniversite İstanbul Üniversitesi olurken; en düşük puanlı tercih edilen üniversite Bartın Üniversitesi olmuştur. 2016 yılı verilerine göre İstanbul Üniversitesini 25.800'üncü sıradaki öğrenci tercih ederken; Bartın üniversitesini ise 75.900'ü öğrenci tercih etmiştir. Farkın bu derece büyük olması kontenjan sayısının fazla olmasından kaynaklı olabilir. Farkın çok yüksek olması, öğretmen adaylarının yeterliliklerinin de farklı olduğu ve bu durumun eğitim-öğretimin kalitesi açısından sorun oluşturabileceği aşikardır. Yine yıllar itibariyle sosyal bilgiler eğitimi anabilim dalını seçen öğrencilerdeki LYS başarısı sürekli gerilemektedir. 2013 yılında en yüksek puanlı kayıt 7140'ıncı olurken; en düşük puanlı kayıt Kafkas Üniversite'sinde 28.200'ci olmuştur. 2016 yılında LYS sırası 75.900'üncülüğe kadar gerilemiştir.

Tablo 5:Üniversitelerin eğitim fakülteleri sosyal bilgiler eğitimi lisans programında görevli eleman sayıları (2008)

\begin{tabular}{|c|c|c|c|c|}
\hline Kadro Derecesi & & iyet & $\mathbf{N}$ & $\%$ \\
\hline \multirow[t]{2}{*}{ Profesör } & $\mathrm{K}$ & 1 & \multirow[t]{2}{*}{16} & \multirow[t]{2}{*}{6,3} \\
\hline & $E$ & 15 & & \\
\hline \multirow[t]{2}{*}{ Doçent } & $\mathrm{K}$ & 2 & \multirow[t]{2}{*}{10} & \multirow[t]{2}{*}{4} \\
\hline & $\mathrm{E}$ & 8 & & \\
\hline \multirow[t]{2}{*}{ Yardımcı Doçent (Doktor Öğretim Üyesi) } & $\mathrm{K}$ & 21 & \multirow[t]{2}{*}{110} & \multirow[t]{2}{*}{43,5} \\
\hline & $\mathrm{E}$ & 89 & & \\
\hline \multirow[t]{2}{*}{ Öğretim Görevlisi } & $\mathrm{K}$ & 17 & \multirow[t]{2}{*}{55} & \multirow[t]{2}{*}{21,7} \\
\hline & $E$ & 38 & & \\
\hline \multirow[t]{2}{*}{ Okutman } & $\mathrm{K}$ & - & \multirow[t]{2}{*}{3} & \multirow[t]{2}{*}{1,2} \\
\hline & $\mathrm{E}$ & 3 & & \\
\hline \multirow[t]{2}{*}{ Uzman } & $\mathrm{K}$ & - & \multirow[t]{2}{*}{1} & \multirow[t]{2}{*}{0,4} \\
\hline & $E$ & 1 & & \\
\hline \multirow[t]{2}{*}{ Araştırma Görevlisi } & $\mathrm{K}$ & 25 & \multirow[t]{2}{*}{58} & \multirow[t]{2}{*}{22,9} \\
\hline & $E$ & 33 & & \\
\hline \multirow[t]{2}{*}{ Toplam } & $\mathrm{K}$ & 66 & \multirow[t]{2}{*}{253} & \multirow[t]{2}{*}{100} \\
\hline & $E$ & 187 & & \\
\hline
\end{tabular}

(Akdağ, 2008:92) 
Tablo 6: Sosyal bilgiler eğitimi anabilim dalında bulunan öğretim elemanı sayıları (2017)

\begin{tabular}{lc}
\hline Öğretim Üyesi Unvanı & Sayı \\
\hline Profesör & 41 \\
\hline Doçent Doktor & 84 \\
\hline Doktor Öğretim Üyesi & 202 \\
\hline Öğretim Görevlisi & 36 \\
\hline Araştırma Görevlisi & 128 \\
\hline Okutman & 3 \\
\hline TOPLAM & $\mathbf{4 9 4}$ \\
\hline
\end{tabular}

Tablo 5 ve Tablo 6 incelendiğine 2008 yılında 253 olan öğretim üyesi sayısı 2017 yılında 494'e çıkmıştır. Yani yaklaşık iki kat öğretim üyesi artışı olmuştur. 2017 yılı verilerine göre Sosyal Bilgiler eğitimi anabilim dallarında bulunan öğretim üyesi sayıları Tablo 6'da verilmiştir. Buna göre 41'i profesör, 84'ü doçent, 202'si Dr. öğretim üyesi olmak üzere Sosyal Bilgiler Eğitimi Anabilim Dalında 327 öğretim üyesi görev yapmaktadır. 128'i Araştırma Görevlisi, 36'sı Öğretim Görevlisi ve 3'ü okutman olmak üzere ise 167 öğretim elemanı görev yapmaktadır. Gazi Üniversitesi 21 kişilik öğretim elemanı sayısıyla birinci sırada yer almaktadır. 14 kişilik akademik kadrosuyla Anadolu, Erzincan, Marmara, İstanbul Üniversiteleri, Gazi Üniversitesi'nden sonra en fazla öğretim elemanına sahip Sosyal Bilgiler Eğitimi Anabilim dallarıdır. 34 üniversitenin sosyal bilgiler eğitimi anabilim dalında profesör kadrosunda öğretim üyesi bulunmamaktadır. Ayrıca sosyal bilgiler eğitimi anabilim dalına sahip 59 üniversiteden 36'sında öğretim üyesi sayısı 8 veya 8'den daha az kişiden oluşmaktadır.

Sosyal bilgiler eğitimi anabilim dallarına gelen öğrencilerin LYS sıralamalarındaki büyük düşüşün en büyük sebebi anabilim dalı mezunlarının atama olanaklarının yıllar itibariyle git gide düşmesidir. Tablo 7'de 2013-2017 yılları arasında Sosyal bilgiler öğretmenliğine ait atama sayları verilmiştir.

Tablo 7: Sosyal bilgiler öğretmenliğine ait atama sayları (2013-2017)

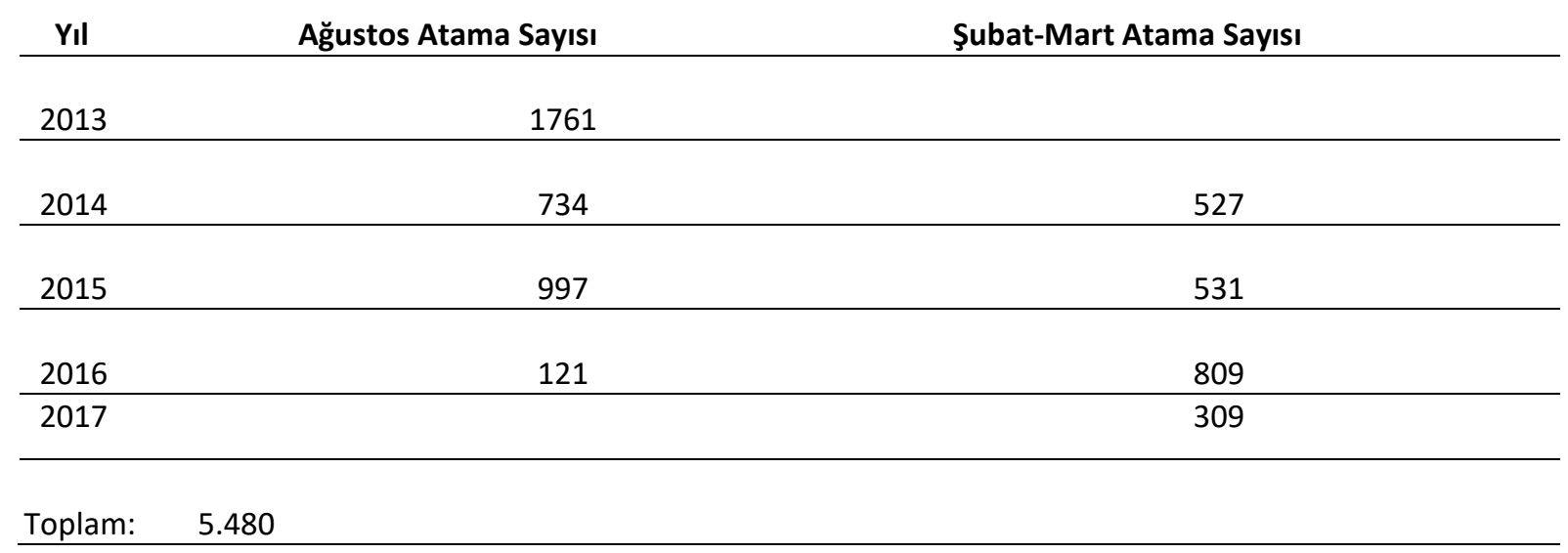


Tablo 7'e incelendiğinde sosyal bilgiler öğretmenliğinin az olan atama sayılarının yıllar içinde daha da azaldığını görmekteyiz. 2013-2017 yılları arasında toplam atama sayısı 5.789'dur. Bu evrede en çok atama 2013 yılı ağustos ayında 1761 kontenjan ile olmuştur. 2016 yılında sınava girenler için 2017 yılı mart ayı sözleşmeli öğretmen olarak yapılacak atamada sosyal bilgiler öğretmenliği alanında sadece 379 kişilik kontenjan açılmıştır. Mezun olan ve KPSS sınavına giren öğretmen adaylarının ortalama sayısının 27.500 olduğu dikkate alındığında atama sayılarının ne derece az olduğu ortaya çıkmaktadır. Mezun sayısının çok fazla olması ve atama sayılarının azalmasıyla birlikte her yıl katlanarak büyüme eğilimi gösteren öğretmen aday sayısı, büyük bir istihdam sorunu da oluşturmuştur.

Sosyal bilgiler öğretmenliğindeki düşük atamalar ve atama sorunu sınava giren aday sayısında da düşüşe sebep olmuştur. 2013-2017 yılları arasında sosyal bilgiler ÖABT sınavına giren aday sayıları Tablo 8'de verilmiştir.

Tablo 8: 2013-2017 yılları arası sosyal bilgiler ÖABT sınavına giren aday sayısı

\begin{tabular}{llllll}
\hline Yıllar & $\mathbf{2 0 1 3}$ & $\mathbf{2 0 1 4}$ & $\mathbf{2 0 1 5}$ & $\mathbf{2 0 1 6}$ & $\mathbf{2 0 1 7}$ \\
\hline Sinava Giren aday sayısı & 19.179 & 22.267 & 24.611 & 23.749 & 19.677 \\
\hline & & & & & Kaynak WEB5-WEB9
\end{tabular}

Tablo 8'den 2013-2017 yılları arasında sosyal bilgiler ÖABT sınavına giren aday sayısına bakıldığında 2013-2015 yılları arasında artan aday sayısının 2016 yılından itibaren düşmeye başladığı ve 2017 yılında (19.677) neredeyse 2013 seviyesine (19.179) gerilediği görülmektedir. Bu durumun başlıca nedeni sınava giren adayların atanamama sorunlarıdır.

Sosyal bilgiler öğretmenliğindeki atama sorununu daha iyi anlamak için 2016 yılı ÖABT sınavına giren diğer tüm branşlardaki aday sayısı ve bunların 2017 mart dönemi atanma oranlarını incelemek gerekir. Bu duruma ait veriler Tablo 9'da verilmiştir.

Tablo 9: 2016 KPSS ÖABT Sınavına giren branşlar, bunların test ortalaması, sınava giren aday sayısı ve 2017 atanma sayısı

\begin{tabular}{|c|c|c|c|c|}
\hline Testler & Ortalama Net & ÖABT Aday Sayısı & 2017 Atanma Sayısı & $\begin{array}{l}\text { ADAY/ATAMA } \\
\text { ORANI \% }\end{array}$ \\
\hline $\begin{array}{l}\text { Illköğretim } \\
\text { Matematik }\end{array}$ & 17,150 & 6.055 & 1.835 & 30.3 \\
\hline $\begin{array}{ll}\text { Yabancı } & \text { Dil } \\
\text { (Ingilizce) } & \end{array}$ & 27,295 & 13.459 & 2193 & 16.3 \\
\hline Sınıf Öğretmeni & 24,338 & 24.739 & 3570 & 14.4 \\
\hline $\begin{array}{l}\text { Din Kültürü ve } \\
\text { Ahlak Bilgisi }\end{array}$ & 25,879 & 24.641 & 2143 & 8.7 \\
\hline $\begin{array}{l}\text { Okul öncesi } \\
\text { öğretmenliği }\end{array}$ & 26,550 & 22.313 & 1720 & 7.7 \\
\hline Rehber Öğretmen & 31,967 & 9.495 & 707 & 7.4 \\
\hline Türkçe & 32,637 & 16.457 & 1140 & 6.9 \\
\hline $\begin{array}{l}\text { Fen Bilimleri/Fen } \\
\text { ve Teknoloji }\end{array}$ & 16,464 & 19.154 & 1.003 & 5.2 \\
\hline Biyoloji & 17,032 & 15.003 & 406 & 2.7 \\
\hline $\begin{array}{ll}\text { Yabancı } & \text { Dil } \\
\text { (Almanca) } & \\
\end{array}$ & 14,239 & 4.074 & 105 & 2.6 \\
\hline Fizik & 15,377 & 10.301 & 239 & 2.3 \\
\hline Kimya & 16,503 & 10.459 & 226 & 2.2 \\
\hline
\end{tabular}


Tablo 9'un devamı

\begin{tabular}{lllll}
\hline Sosyal Bilgiler & $\mathbf{2 9 , 2 4 2}$ & $\mathbf{2 3 . 7 4 9}$ & $\mathbf{3 7 9}$ & $\mathbf{1 . 6}$ \\
\hline Coğrafya & 25,511 & 10.295 & 143 & 1.4 \\
\hline $\begin{array}{l}\text { Türk Dili ve } \\
\text { Edebiyatı }\end{array}$ & 22,816 & 46.619 & 618 & 1.3 \\
\hline Matematik (Lise) & 9,994 & & 343 & 1.2 \\
\hline Tarih & 27,039 & 27.863 & 185 & 0.68 \\
\hline
\end{tabular}

Tablo 9 incelendiğinde ÖABT sınavına giren adaylar arasında en yüksek atama oranının \%30.3 ile ilköğretim matematik branşına ait olduğu görülürken, ilköğretim matematik branşını takip eden diğer branşların ise İngilizce öğretmenliği (\%16.3) ve sınıf öğretmenliği (\%14.4) olduğu görülmektedir. Sınava giren aday sayısına göre aday/atama oranı en düşük olan branşlar ise tarih öğretmenliği (\%0.68), lise matematik öğretmenliği (\%1.2), Türk dili ve edebiyatı öğretmenliği (\%1.3), coğrafya öğretmenliği (\%1.4) ile sosyal bilgiler öğretmenliği (\%1.4) olduğu görülmektedir. ÖABT sınavına giren adaylar arasında aday/atama oranı en az olan branşların ortaöğretim yani lise branşları olduğu dikkat çekerken ortaokul ve ilköğretime dönük branşlar arasında en az aday/atama oranına sahip branş sosyal bilgiler öğretmenliği olmuştur. Bu durum sosyal bilgiler öğretmenliği adaylarının ÖABT sınavına girme oranını da düşürmeye başlamıştır. 2015 yılında sosyal bilgiler alanında 24.611 aday sınava girerken bu sayı 2016 yılında 23.749'e 2017 yılında ise 19.677'e gerilemiştir. 2017 yılında 2016 yılına göre sosyal bilgiler branşında sınava giren aday sayısında yaklaşık 3800 yeni mezunda eklenmesine rağmen 2016 yılına göre 2017 yılında sınava giren aday sayısında \%20.7'lik bir düşüş olmuştur.

\section{Tartışma ve Sonuç}

Bu araştırmada, Türkiye'de ki eğitim fakültelerinde sosyal bilgiler eğitimi anabilim dalına ilişkin bir envanter çalışması yapılmıştır. 2013-2017 yılları arası ÖSYM yükseköğretim programları ve kontenjanları kılavuzları ve ilgili bölümlerin internet ortamındaki ulaşılabilir bilgi ve belgelerinin incelenmesi ve değerlendirilmesi neticesinde aşağıdaki sonuçlara ulaşılmıştır.

Türkiye üniversitelerinde 2017 yılında 59 sosyal bilgiler öğretmenliği anabilim dalı aktif bir şekilde bulunmaktadır. 1997-1998 yılından önce sadece iki fakülte (Gazi Üniversitesi'ne bağlı bir fakülte olan Kastamonu Eğitim Fakültesi ve Celal Bayar Üniversitesi Demirci Eğitim Fakültesi) sosyal bilgiler öğretmenliği lisans programına öğrenci alımı yaparken; bu sayı 1998-1999 eğitim-öğretim yılında yani YÖK'ün eğitim fakültelerini tekrar yapılandırdığı yılda 28'e; 2017 yılında ise 59'a yükselmiştir. Sosyal bilgiler öğretmenliği anabilim dallarının 2012'den bu yana sadece örgün öğretim öğrencisi bulunmakta, hiçbir programda ikinci öğretim faaliyeti yürütülmemektedir.

Aktif öğrencisi bulunan sosyal bilgiler eğitimi anabilim dallarında toplam 15.639 öğrenci bulunmaktadır. 59 üniversite içerisinde öğrenci sayısı en fazla olan üniversiteler 372 öğrenci ile Atatürk, Celal Bayar, Cumhuriyet, Dokuz Eylül, Erzincan, Gazi, Karadeniz Teknik (2018'den itibaren Trabzon), Kastamonu, Necmettin Erbakan, Niğde Ömer Halisdemir, Pamukkale ve Siirt Üniversiteleridir. 1-2-3-4 sınıfında 
öğrencisi bulunan üniversiteler içerisinde en az öğrencisi olan üniversite ise 31 öğrenci ile Bayburt, 41 öğrenci ile Bozok Üniversitesidir. Sosyal Bilgiler Öğretmenliği anabilim dalın öğrenci sayıları oldukça fazladır. Fazla açılan kontenjanlar bunun en önemli sebebidir. Bu durum eğitim öğretim faaliyetlerinin etkili bir şekilde yapılmasını engelleyebilir ve kalitesini düşürebilir.

Sosyal bilgiler eğitimi anabilim dalına yerleşen öğretmen adaylarının LYS puan sıraları arasındaki büyük fark dikkat çekmektedir. 2013-2016 yılı verilerine göre sosyal bilgiler eğitimi anabilim dallarına yerleşen en yüksek puanlı öğrencilerin tercih ettikleri üniversite İstanbul Üniversitesi olurken; en düşük puanlı tercih edilen üniversite Bartın Üniversitesi olmuştur. 2016 yılı verilerine göre İstanbul Üniversitesini 25.800'üncü sıradaki öğrenci tercih ederken; Bartın üniversitesini ise 75.900'ü öğrenci tercih etmiştir. Yine yıllar itibariyle sosyal bilgiler eğitimi anabilim dalını seçen öğrencilerdeki LYS başarısı sürekli gerilemektedir. 2013 yılında en yüksek puanlı kayıt 7140'ıncı olurken; en düşük puanlı kayıt Kafkas Üniversite'sinde 28.200'ci olmuştur. 2016 yılında LYS sırası 75.900'üncülüğe kadar gerilemiştir. Bu sonuçlara göre anabilim dalına girişte esas alınan LYS puan alt ve üst sıraları arasındaki fark oldukça yüksektir. Bu durum anabilim dalına kayıt yaptıran öğrencilerin bilgi seviyesi ve akademik başarısı arasında da farkın çok olabileceğini ve değişkenlik gösterebileceği sonucunu ortaya koymaktadır.

2017 yılı verilerine göre Sosyal Bilgiler eğitimi anabilim dallarında bulunan öğretim elemanı sayısı 494'dür. Sosyal bilgiler eğitimi anabilim dalına sahip 59 üniversiteden 36'sında öğretim üyesi sayısı 8 veya 8'den daha az kişiden oluşmaktadır. Öğretim üyesi azlığı Türkiye'deki üniversitelerin ortak sorunudur. Sosyal bilgiler eğitimi anabilim dalları da bu sorunu yaşamaktadır. Bu durum yeterince doğru planlama yapılmadan üniversitelerde anabilim dallarının açılmasının bir sonucudur. Öğretim üyesinin az olması eğitim öğretim faaliyetlerinin kalitesini de etkilemektedir. Öğretim üyesinin ders yükü artmakta, kendi uzmanlık alanının dışında derslere girmek zorunda kalmakta, akademik araştırma yapmaya yeterince zaman ayıramamaktadır.

Yıllar itibariyle sosyal bilgiler öğretmenliği anabilim dalı sayısı artmaktadır. Bu durum anabilim dalının mezun öğrenci sayısını da arttırmaktadır. Anabilim dalı mezunları Sosyal Bilgiler öğretmeni olmak için bu programa gelmektedir. Devlet kadrolarında Sosyal Bilgiler öğretmeni istihdamının da kısıtlı olması program öğrencileri için bugün ve gelecekte sıkıntı oluşturmakta ve motivasyon kaybına neden olmaktadır. 2016 yılı verilerine göre sınava giren aday sayısına göre aday/atama oranı en düşük olan branşlardan birisi de \%1.4'lük oranıyla sosyal bilgiler öğretmenliği programı olmuştur. ÖABT sınavında, sınava giren aday/atama oranı en düşük programların lise branşları olduğu görülürken (tarih öğretmenliği (\%0.68), lise matematik öğretmenliği (\%1.2), Türk dili ve edebiyatı öğretmenliği (\%1.3), coğrafya öğretmenliği (\%1.4) 2016 yılında ÖABT sınavına girip 2017 yılında ataması yapılan öğretmen adaylarında ilköğretim ve ortaokul branşları içinde en düşük oran maalesef sosyal bilgiler eğitimi anabilim dalı olmuştur. Bu durum sosyal bilgiler eğitimi anabilim dalından mezun olan adaylarda bir motivasyon kaybı yaratmaktadır. Bu durumun en somut örneği 2013-2017 sosyal bilgiler ÖABT sınavına giren aday sayısında 
görülmektedir. 2013'den 2015'e kadar sürekli artan aday sayısı 2015'den itibaren düşüş göstermeye başlamıştır. ÖABT sosyal bilgiler sınavına giren aday sayısı 2013 yılında 19.179; 2014 yılında 22.267; 2015 yılında 24.611; 2016 yılında 23.749 ve 2017 yılında 19.677 kişi olmuştur. 2017 yılında 2016 yılı sınavına göre ÖABT sınavına giren aday sayısında 4072 kişi yani \%20.7'lik düşüş yaşanmıştır. 2016 yılında yaklaşık 3800 yeni mezun veren sosyal bilgiler öğretmenliği anabilim dalında bu rakamda göz önüne alındığında bir kısım öğretmen adayının öğretmen olmaktan umudu kestiği anlaşılmaktadır. ÖABT sınavıyla öğretmen olamayacağını düşünen özellikle erkek adaylar bu sınava girmek yerine gardiyanlık, polislik, astsubaylık gibi güvenlikle ilgili devlet kurumlarına ya da başka alanlardaki sınavlara müracaat etmektedir. Kısaca bu sınavlar öğretmen adaylarının üzerinde olumsuz bir etki bırakmaktadır. Gündoğdu, Çimen ve Turan (2008) ile Atav ve Sönmez (2013)'de yaptıkları çalışmada öğretmen adaylarının KPSS sınavın geleceklerini etkilediği için çok önemli olduğunu, ancak bu sınavın ve sınava hazırlanma sürecinin kendilerini ruhen, ekonomik ve sosyal olarak yıprattığını; sınavın iyi öğretmen seçen bir sistem olmadığını ve genel olarak KPSS'nin kaygı düzeyleri üzerinde olumsuz bir etki yarattığını söylemektedir.

\section{Öneriler}

Araştırma sonuçlarına göre aşağıdaki öneriler getirilmiştir.

Sosyal Bilgiler Öğretmenliği anabilim dallarında eğitim öğretim faaliyetlerinin verimliliği, öğrenci sayısının çok fazla olmasına bağlı olarak düşmektedir. Bunun için yeni anabilim dallarının açılmasının durdurulması ve kontenjan sayılarının azaltılması gerekmektedir.

Sosyal Bilgiler Öğretmenliğinin atama sayıları çoğaltılmalı, istihdam olanakları artırılmalı, binlerce mezun öğretmen adayı açık olan kadrolara yerleştirilmeli ve buna uygun politikalar geliştirilmelidir.

Türkiye nitelikli öğretmenler yetiştirmek için yeni politikalar geliştirmeli, öğretmen eğitiminde sorumlu olanlar, nitelikli öğretmen yetiştirmede, istihdamın en önemli unsur olduğunu unutmamalıdır.

Milli Eğitim Bakanlığı, sözleşmeli ve ücretli öğretmenlik uygulamalarına son vermeli, öğretmenlik dalları arasındaki kadroların dağılımında daha faydalı olacak fikirler uygulamalıdır.

\section{Kaynaklar}

Açıkgül, K., Macit, E., \& Çakan, C. (2015). Lise, dershane ve üniversitede verilen matematik eğitiminin ilköğretim matematik öğretmen adayları tarafından değerlendirilmesi. Adıyaman Üniversitesi Eğitim Bilimleri Dergisi, 5(1), 72-98.

Akdağ, H. (2008). İlköğretim 6. ve 7. sınıf sosyal bilgiler öğretim programının öğretmen ve öğrenci açısından uygulama dönütleri. Yayınlanmamış doktora tezi. Gazi Üniversitesi eğitim bilimleri enstitüsü, Ankara. 
Akdağ, H. (2009). Sosyal bilgilerin tanımı, amacı, önemi ve Türkiye'deki yeri. R. Turan; A.M.Sünbül; H. Akddağ (Ed.). Sosyal Bilgiler Öğretiminde yeni yaklaşımlar 1 İçinde (s.2-24). Ankara: Pegem Akademi.

Ata, B. (2007). Yeni sosyal bilgiler öğretmenliği lisans programının ilköğretim 2005 sosyal bilgiler dersi $(6,7$. sınıflar) öğretim programı açısından değerlendirilmesi. I. Uluslararası Bilim Çalıştayı (Prof. Dr. Suzan ERBAŞ Anısına), Çanakkale Onsekiz Mart Üniversitesi, Eğitim Fakültesi, İlköğretim Bölümü, 08-09 Mart, Çanakkale. acikarsiv.gazi.edu.tr/File.php?Doc_ID=74

Atav, E., ve Sönmez, S. (2013). Öğretmen adaylarının kamu personeli seçme sınavı (KPSS)'na ilişkin görüşleri. Hacettepe Üniversitesi Eğitim Fakültesi Dergisi, Özel Sayı, 1, 01-13.

Aydın, A. (1998). Eğitim fakültelerinin yeniden yapılandırılması ve öğretmen yetiştirme sorunu, Kuram ve Uygulamada Eğitim Yönetimi. 15, 275-286.

Çetin, K. (2003). Türk eğitim tarihinde sosyal bilimler ve sosyal bilgilerin tarihsel süreçleri, Atatürk Üniversitesi Sosyal Bilimler Enstitüsü Dergisi, 2(1-2).

Dursunoğlu, H. (2003). Cumhuriyet Döneminde İlköğretime Öğretmen Yetiştirmenin Tarihi Gelişimi. Milli Eğitim 160. https://dhgm.meb.gov.tr/yayimlar/dergiler/Milli_Egitim_Dergisi/160/dursunoglu. htm adresinden 05 Ağustos 2017 tarihinde indirilmiştir.

Gündoğdu, K., Çimen, N., \& Turan, S. (2008). Öğretmen adaylarının kamu personeli seçme sınavına (KPSS) ilişkin görüşleri. Ahi Evran Üniversitesi Kırşehir Eğitim Fakültesi Dergisi, 9(2), 35-43.

Gürbüz, R., Erdem, E., Temurtaş, A., ve Aygen, KOÇ (2015). ÖSYS Başarısını Etkileyen Faktörler: Adıyaman İli Örneği. Adıyaman Üniversitesi Eğitim Bilimleri Dergisi, 5(1), 49-71.

İbret, B. Ü. ve Kaymakcı, S. (2016). Türkiye'de sosyal bilgiler öğretmeni yetiştirmede ilklerden biri: Kastamonu eğitim fakültesi sosyal bilgiler öğretmenliği programı. V. Uluslararası Sosyal Bilgiler Eğitimi Sempozyumu'nda sunulmuş bildiri, Pamukkale Üniversitesi, Denizli, 28-30 Nisan.

Kaymakcı, S. (2012). Sosyal bilgiler öğretmenliği lisans programlarının içerik değerlendirmesi. Uluslararası Sosyal Bilimler Eğitimi Dergisi (USBED)/International Social Science Education of Journal (ISSEJ), 2 (1).

Kılıçoğlu, G. (2015). Sosyal bilgilerin tanımı, dünyada ve ülkemizde gelişimi ve önemi. M.Safran (Ed.). Sosyal bilgiler öğretimi içinde (s.3-16). Ankara: Pegem Akademi.

Kızılçaoğlu, A. (2005). Eğitim fakültelerinde yeniden yapılandırma sürecine ilişkin eleştiriler ve öneriler. Balıkesir Üniversitesi Sosyal Bilimler Enstitüsü Dergisi, 14(1), 132-140.

Özav, L. (2001). Sosyal bilgiler öğretmenliği lisans programı üzerine düşünceler. Afyon Kocatepe Üniversitesi Sosyal Bilimler Dergisi, 3 (1), s. 165-177. 
Öztürk, C. (2012). Sosyal bilgiler: toplumsal yaşama disiplinlerarası bir bakış. C.Öztürk (Ed.). Sosyal bilgiler öğretimi demokratik vatandaşlık eğitimi içinde (s.1-31). Ankara: Pegem Akademi.

Öztürk, C. ve Otluoğlu, R. (2002). Sosyal bilgiler öğretiminde edebi ürünler ve yazılı materyaller. Ankara: Pegem Akademi.

Safran, M. (2011). Sosyal bilgiler öğretimine bir bakış. B. Tay, A. Öcal (Ed.). Özel Öğretim Yöntemleriyle Sosyal Bilgiler Öğretimi içinde (s.2-18). Ankara: Pegem Akademi.

Safran, M., Kan, A., Üstündağ, M.T., Birbudak, T.S., Yıldırım, O. (2014). 2013 KPSS sonuçlarının öğretmen adaylarının mezun oldukları alanlara göre incelenmesi. Eğitim ve bilim, 39 (171), 13-25.

Sağlamer, E. (1980). İlkokulda sosyal bilgiler öğretimi. Ankara:Tek Işık Matbaası Yayınları.

Yıldırım, A. ve Şimşek, H. (2000). Sosyal bilimlerde nitel araştırma yöntemleri. Gözden geçirilmiş 2. Baskı. Ankara: Seçkin Yayıncılık.

YÖK. (1998). Eğitim fakültesi öğretmen yetiştirme lisans programları. http://www.yok.gov.tr/documents/10279/30217/Egitim_fakultesi_ogretmen_yeti stirme_lisans_programlari_mart_98.pdf/5e166018-b806-48d5-ae13-

6afd5dac511c adresinden 10 şubat 2017 tarihinde alınmıştır.

\section{İnternet Adresleri}

WEB1:https://www.tbmm.gov.tr/tutanaklar/TUTANAK/TBMM/d20/c021/b060/tbmm20 0210600219.pdf

WEB2:http://www.gazetevan.com/Mehmet-Fatih-Isik/607/DUNDEN-BUgUNE-DMSKMS-KPSS-VE-SONRASI.html)

WEB3:https://tedmem.org/dosya-konusu/prof-dr-mustafa-safran-ile-ogretmenistihdam-politikalari-uzerine-bir-soylesi)

WEB4:https://yokatlas.yok.gov.tr/tercih-sihirbazi-t3.php

WEB5:https://dokuman.osym.gov.tr/pdfdokuman/2013/KPSS1/2013KPSS\%20A\%20GRUBU\%20ve\%20\%C3\%96\%C4\%9ERETMENL\%C4\%BOK. pdf

WEB6:https://dokuman.osym.gov.tr/pdfdokuman/2014/KPSS/OABTSORUYANIT/KPSS-2014-OABTsayisal25072014.pdf

WEB7:https://dokuman.osym.gov.tr/pdfdokuman/2015/kpss/2015kpss_sayisabilgiler2 8082015.pdf

WEB:8https://dokuman.osym.gov.tr/pdfdokuman/2016/KPSS/OABT/OABTSonucSayi salBilgiler02092016.pdf

WEB9:https://dokuman.osym.gov.tr/pdfdokuman/2017/KPSS/OABT/SayisalBilgiler04 082017.pdf 